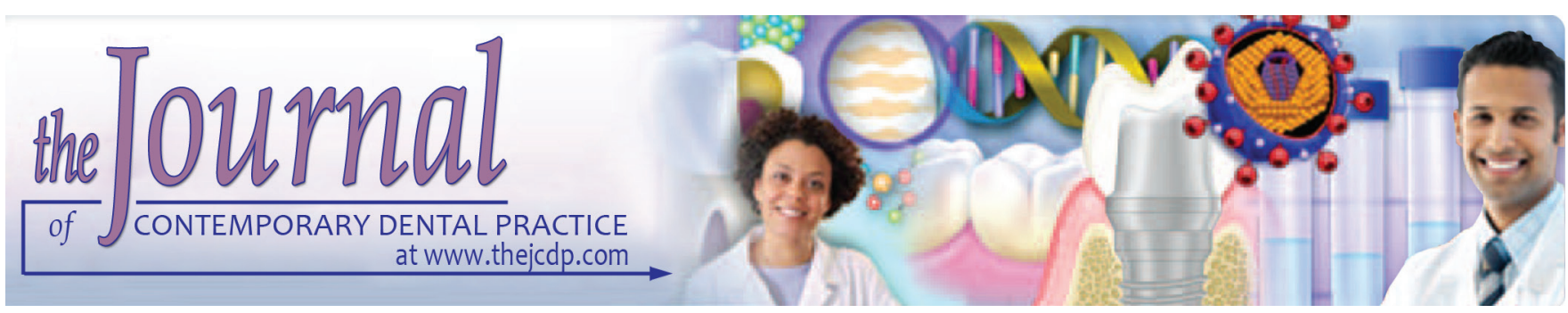

\title{
Influence of Television Advertising on Behavior of Children across Socioeconomic Backgrounds
}

\author{
${ }^{1}$ Rachana Bahuguna, ${ }^{2}$ Atul Jain, ${ }^{3}$ Divya Suryavanshi, ${ }^{4}$ Hemlata Chauhan, ${ }^{5}$ Suleiman A Khan, ${ }^{6}$ Ruchi Thakur
}

\begin{abstract}
Introduction: This research analyzed the influence of television on the behavior of children belonging to urban and rural socioeconomic backgrounds of Bhopal city and its vicinity.
\end{abstract}

Materials and methods: About 400 parents with children between 1 and 18 years of age were subjected to a self-designed questionnaire, which sought information regarding the television viewing habits of children. Differences in responses were noted between the subjects of urban and rural areas. Obtained data were subjected to statistical analysis using Pearson's chi-square test to determine the level of significance.

Results: The urban class showed a dominating pattern in the positive aspects of television viewing, such as significantly better awareness of oral health, more emphasis shown toward oral care adverts, and a higher knowledge of the cause of dental caries. However, the urban class also possessed a poor attitude; the appearance of a dentist on television did not remind them about oral needs, products with gifts pleased their children to a greater extent, they had more demanding children, parents fulfilled their children's demand more, and they relied on the self for selection of toothpaste. Overall, in all aspects, the rural class lacked significantly.

Conclusion: Television exerts a positive as well as negative influence on children's behavior among urban and rural communities, with the influence being more obvious in the urban class.

Clinical significance: The results of this study can be utilized in bringing about better and effective advertising oriented toward attaining optimum oral health of children; overall general health

1,3,4,6 Department of Pedodontics, RKDF Dental College and Research Centre, Bhopal, Madhya Pradesh, India

${ }^{2}$ Department of Conservative Dentistry and Endodontics RKDF Dental College and Research Centre, Bhopal, Madhya Pradesh, India

${ }^{5}$ Department of Pedodontics, Saraswati Dental College and Hospital, Lucknow, Uttar Pradesh, India

Corresponding Author: Rachana Bahuguna, Department of Pedodontics, RKDF Dental College and Research Centre Bhopal, Madhya Pradesh, India, Phone: +917898488813 e-mail: rachanabahuguna71@gmail.com through adverts that discourage obesogenic diet and promote a diet rich in protein and fiber can also be focused on.

Keywords: Children's behavior, Food promotion, Oral health, Television advertising, Urban and rural.

How to cite this article: Bahuguna R, Jain A, Suryavanshi $D$, Chauhan H, Khan SA, Thakur R. Influence of Television Advertising on Behavior of Children across Socioeconomic Backgrounds. J Contemp Dent Pract 2017;18(1):52-56.

Source of support: Nil

Conflicts of interest: None

\section{INTRODUCTION}

The impact of television advertising on viewers is incomparable to any other media, as it is one of the most common and effective media sources. ${ }^{1}$ The aim of advertising is to make a product famous and known to a large volume of buyers with an option of being creative. ${ }^{2,3}$ This is easily achieved through television as most households own a television set. Since the transformation of the society has been led by consumerism in the last few decades, aspirations have soared and double income families are quite common. Consequently, children are more in control of their lives. Their free time is spent watching television or browsing on the Internet.

Advertising delivers reliable information regarding a product or service in an impersonal manner. ${ }^{4}$ Children, being future consumers, constitute a crucial demographic section to advertisers, as they can influence their parents' purchase habits. ${ }^{5}$ Parents are compelled to buy products out of affection for their kids. Advertisers being opportunists target children for selling products, whether a toy or gadget, insurance policies, or even cars. ${ }^{6}$ They employ different strategies to approach children through portrayal of fun, live action, music, emotion, etc. Consumer segmentation has given a new dimension to marketing. Research suggests that kids enjoy entertaining advertisements, especially musical and hilarious ones or cartoons. ${ }^{7}$ 
$\mathrm{McNeal}^{8}$ reported that the number of parents who include children on certain purchase decisions has been gradually increasing over the decades. Reportedly, the attitude toward an advert influences the chances of purchase of a product. ${ }^{9}$ The attitudinal effects have been explained on the basis of like or dislike of an advert. Unlike older children, young children are unable to understand the profit motive behind advertising. ${ }^{10}$ Peer pressure and viewing time also exert significant influence over children's buying behavior. ${ }^{11}$ Regardless of the negative aspects of advertising and its influence on children, it has certain advantages as well. It can also be utilized as a tool to promote general health by advertising nutritious food, while discouraging sugar-rich snacks and other food and beverages. The benefits of oral health maintenance can be outlined and efforts made to inculcate good oral health behavior. This will help in reducing the burden of obesity, which has negatively impacted health and reduced quality of life. Literature is replete with research on television advertising and its influence on the behavior of children. However, a study that analyzes the differences in the impact of advertising on children belonging to urban and rural socioeconomic backgrounds has not been conducted so far. To this effect, a study was conducted on children between 1 and 18 years of age by interviewing parents belonging to different social classes.

\section{MATERIALS AND METHODS}

The study was based on primary data. Data were collected by means of a structured questionnaire. Parents of children whose behavior had to be analyzed were selected as respondents for the study. A total of 400 respondents were selected. Out of these, 200 belonged to urban areas and 200 were from rural areas of Bhopal, Madhya Pradesh. The study protocol received institutional approval from

Table 1: Favorite and most influencing source of media for children

\begin{tabular}{lllll}
\hline & Value & Df & $\begin{array}{l}\text { Asymp. Sig. } \\
\text { (2-sided) }\end{array}$ & $\begin{array}{l}\text { Exact Sig. } \\
\text { (2-sided) }\end{array}$ \\
\hline Pearson Chi-square & 6.122 & 1 & 0.013 & \\
$\begin{array}{l}\text { Continuity correction } \\
\text { Likelihood ratio }\end{array}$ & 2.721 & 1 & 0.099 & \\
$\begin{array}{l}\text { Fischer's exact test N } \\
\text { of valid cases }\end{array}$ & 100 & 1 & 0.017 & 0.061 \\
\hline
\end{tabular}

Table 3: Children's reaction to viewing adverts

\begin{tabular}{|c|c|c|c|c|}
\hline & Value & $D f$ & $\begin{array}{l}\text { Asymp. Sig. } \\
\text { (2-sided) }\end{array}$ & $\begin{array}{l}\text { Exact Sig. } \\
\text { (2-sided) }\end{array}$ \\
\hline Pearson Chi-square & 46.023 & 1 & 0.000 & \\
\hline Continuity correction & 43.226 & 1 & 0.000 & \\
\hline Likelihood ratio & 59.779 & 1 & 0.000 & \\
\hline $\begin{array}{l}\text { Fischer's exact test } \mathrm{N} \\
\text { of valid cases }\end{array}$ & 100 & & & 0.000 \\
\hline
\end{tabular}

the ethical committee of RKDF Dental College and Research Centre, Bhopal.

The questionnaire consisted of 10 multiple choice questions and was oriented toward obtaining information on television-mediated marketing and its influence on the behavior of children. There were some questions regarding oral health behavior and knowledge of oral health. The percentage of the majority of respondents selecting a particular choice from urban and rural areas was measured for each television viewing parameter.

Data were analyzed by Statistical Package for the Social Sciences (SPSS) software. Chi-square tests were conducted to determine the level of significance for each television viewing parameter.

\section{RESULTS}

Parents from different socioeconomic backgrounds were interviewed regarding their children's television viewing habits. Chi-square tests were conducted to reveal whether the difference between the two classes was significant or not.

About $98 \%$ of urban and $75 \%$ of rural parents believed that television was the most common source of media exposure for children (Table 1). That children watched adverts in between their favorite programs was agreed upon by $75.5 \%$ of urban parents interviewed, but only by $63 \%$ of those from rural areas (Table 2). Children making demands after watching advertisements was felt by $64 \%$ urban and $45 \%$ rural parents (Table 3 ). Parent's reaction to the child's demand for the product that elicited a favorable response toward the child was seen in $71 \%$ urban and $49 \%$ rural parents; these are parents who were influenced and fulfilled demands, whereas the rest evaluated neediness first (Table 4). Small gifts with products appealed to

Table 2: Watching adverts in between the program

\begin{tabular}{lllll}
\hline & \multicolumn{4}{c}{$\begin{array}{l}\text { Asymp. } \\
\text { Sig. }\end{array}$} \\
& Value & Df & $\begin{array}{l}\text { Exact Sig. } \\
\text { (2-sided) }\end{array}$ & (2-sided) \\
\hline Pearson Chi-square & 53.770 & 1 & & \\
Continuity correction & 50.272 & 1 & & \\
Likelihood ratio & 62.243 & 1 & 0.000 & 0.000 \\
$\begin{array}{l}\text { Fischer's exact test N of } \\
\text { valid cases }\end{array}$ & 100 & & & \\
\hline
\end{tabular}

Table 4: Parent's reaction to child's demand for a particular product

\begin{tabular}{|c|c|c|c|c|c|}
\hline & Value & $D f$ & $\begin{array}{l}\text { Asymp. } \\
\text { Sig. } \\
\text { (2-sided) }\end{array}$ & $\begin{array}{l}\text { Exact } \\
\text { Sig. } \\
\text { (2-sided) }\end{array}$ & $\begin{array}{l}\text { Exact } \\
\text { Sig. } \\
\text { (1-sided) }\end{array}$ \\
\hline Pearson chi-square & 39.243 & 1 & 0.000 & & \\
\hline Continuity correction & 36.530 & 1 & 0.000 & & \\
\hline Likelihood ratio & 50.693 & 1 & 0.000 & & \\
\hline $\begin{array}{l}\text { Fischer's exact test } \\
\mathrm{N} \text { of valid cases }\end{array}$ & 100 & & & 0.000 & 0.000 \\
\hline
\end{tabular}


Table 5: Influence of small gifts with product

\begin{tabular}{llllll}
\hline & & & $\begin{array}{l}\text { Asymp. } \\
\text { Sig. }\end{array}$ & $\begin{array}{l}\text { Exact } \\
\text { Sig. }\end{array}$ & $\begin{array}{l}\text { Exact } \\
\text { Sig. }\end{array}$ \\
& Value & Df & (2-sided) & $\begin{array}{l}\text { (2-sided) } \\
\text { (1-sided) }\end{array}$ \\
\hline Pearson Chi-square & 52.703 & 1 & 0.000 & & \\
$\begin{array}{l}\text { Continuity correction } \\
49.378\end{array}$ & 1 & 0.000 & & \\
Likelihood ratio & 62.816 & 1 & 0.000 & & \\
$\begin{array}{l}\text { Fischer's exact test } \\
\text { N of valid cases }\end{array}$ & 100 & & & 0.000 & 0.000 \\
\hline
\end{tabular}

Table 7: Whether appearance of a dentist on television reminds parents of oral needs

\begin{tabular}{|c|c|c|c|c|c|}
\hline & Value & $D f$ & $\begin{array}{l}\text { Asymp. } \\
\text { Sig. } \\
\text { (2-sided) }\end{array}$ & $\begin{array}{l}\text { Exact } \\
\text { Sig. } \\
\text { (2-sided) }\end{array}$ & $\begin{array}{l}\text { Exact } \\
\text { Sig. } \\
\text { (1-sided) }\end{array}$ \\
\hline Pearson Chi-square & 63.211 & 1 & 0.000 & & \\
\hline Continuity correction & 59.910 & 1 & 0.000 & & \\
\hline Likelihood ratio & 78.882 & 1 & 0.000 & & \\
\hline $\begin{array}{l}\text { Fischer's exact test } \\
\mathrm{N} \text { of valid cases }\end{array}$ & 100 & & & 0.000 & 0.000 \\
\hline
\end{tabular}

Table 9: Method of selection of toothpaste

\begin{tabular}{|c|c|c|c|}
\hline & Value & $D f$ & $\begin{array}{l}\text { Asymp. Sig. } \\
\text { (2-sided) }\end{array}$ \\
\hline Pearson Chi-square & 96.212 & 6 & 0.000 \\
\hline Likelihood ratio & 127.707 & 6 & 0.000 \\
\hline Fischer's exact test $\mathrm{N}$ of valid cases & 100 & & \\
\hline
\end{tabular}

$74 \%$ urban and $60 \%$ rural kids with a significant difference (Table 5). The remaining parameters were concerned with knowledge of oral care. The importance of oral care advertisements to be featured on television was emphasized by $79 \%$ urban and by only $43 \%$ rural parents (Table 6 ).

To the appearance of a dentist on television serving as a reminder for dental needs, about $65 \%$ urban and 55\% rural parents gave a negative opinion (Table 7). About $55 \%$ urban and $52 \%$ rural parents thought dental caries was related to sugar intake (Table 8 ). About $53 \%$ of urban and $38 \%$ rural parents relied on themselves for selection of toothpaste (Table 9). About $61 \%$ of urban and $43 \%$ rural parents thought that similar preventive measures regarding oral health could be followed for themselves and children (Table 10). For all the variables, a statistically significant difference was noted between the two classes. Results of chi-square tests for each variable are enlisted in Tables 1 to 10.

\section{DISCUSSION}

Television viewing is a common leisure time indulgence for children across the globe. ${ }^{12}$ It is common knowledge that children watch advertisements in between their favorite channel programs, such as cartoons, etc., as they find them interesting. Companies aggressively market products through advertising in between programs to
Table 6: Opinion on importance of oral care adverts

\begin{tabular}{llllll}
\hline & \multicolumn{3}{c}{$\begin{array}{l}\text { Asymp. } \\
\text { Sig. }\end{array}$} & $\begin{array}{l}\text { Exact } \\
\text { Sig. }\end{array}$ & $\begin{array}{l}\text { Exact } \\
\text { Sig. }\end{array}$ \\
& Value & Df & (2-sided) & (2-sided) & (1-sided) \\
\hline Pearson Chi-square & 25.540 & 1 & 0.000 & & \\
Continuity correction & 23.118 & 1 & 0.000 & & \\
Likelihood ratio & 33.687 & 1 & 0.000 & & \\
$\begin{array}{l}\text { Fischer's exact test } \\
\text { N of valid cases }\end{array}$ & 100 & & & 0.000 & 0.000 \\
\hline
\end{tabular}

Table 8: According to views aired as to how caries can be prevented

\begin{tabular}{llll}
\hline & Value & Df & $\begin{array}{l}\text { Asymp. Sig. } \\
(2-\text { sided })\end{array}$ \\
\hline Pearson Chi-square & 138.870 & 4 & 0.000 \\
Likelihood ratio & 149.588 & 4 & 0.000 \\
$\begin{array}{l}\text { Fischer's exact test N of } \\
\text { valid cases }\end{array}$ & 100 & & \\
\hline
\end{tabular}

Table 10: Whether the same preventive measures should be followed for parents and children

\begin{tabular}{llllll}
\hline & & & $\begin{array}{l}\text { Asymp. } \\
\text { Sig. }\end{array}$ & $\begin{array}{l}\text { Exact } \\
\text { Sig. }\end{array}$ & $\begin{array}{l}\text { Exact } \\
\text { Sig. }\end{array}$ \\
& Value & Df & $\begin{array}{l}\text { (2-sided) } \\
\text { (2-sided) }\end{array}$ & (1-sided) \\
\hline Pearson Chi-square & 46.333 & 1 & 0.000 & & \\
Continuity correction & 41.968 & 1 & 0.000 & & \\
Likelihood ratio & 45.103 & 1 & 0.000 & & \\
$\begin{array}{l}\text { Fischer's exact test } \\
\text { N of valid cases }\end{array}$ & 100 & & & 0.000 & 0.000 \\
\hline
\end{tabular}

enhance profit margins. Young children are psychologically and cognitively susceptible to its underlying commercial motive. ${ }^{13}$ Documentation from previous research suggests that only $25 \%$ of 11 - to 12 -years-olds are able to explain advertising motives in terms of selling and profit. $^{14}$

Children view advertising as being informative and entertaining in nature due to lack of cognitive development. Several food products advertised on television have obesogenic potential. That food promotion has an effect particularly on children's preferences, purchase behavior, and consumption has been concluded by evidence reviews. ${ }^{15-17}$ Globally, childhood obesity, which has health implications for life, has shown an alarming increase in recent decades.

This study examined the behavioral influence exerted by television viewing on children based on a questionnaire that sought opinions from parents belonging to different socioeconomic backgrounds. Television emerged as the most common source of media exposure for children as reported by urban and rural parents. They complained that children became demanding after watching adverts. In this study, despite agreement between urban and rural parents on television as the most common media source 
and children making demands, a statistically significant difference was demonstrated between the two classes. Greater exposure of urban kids favored their demanding nature. Lesser exposure to adverts broadcast and discipline enforced on rural kids by their parents might have resulted in them watching fewer adverts and making fewer demands. Advert exposure has been related to increased requests for certain products, ${ }^{18}$ and this applies equally to food adverts as well as toy adverts. ${ }^{19}$ A recent cross-cultural study involving many countries demonstrated a significant association between the advert exposure and childhood obesity. ${ }^{20}$ Consumer segmentation intensifies child-oriented marketing. Gifts clubbed with products please children regardless of their intent. They tend to make the display more attractive. In this study, gifts pleased urban kids significantly more than rural ones. Again, greater availability of such products in the vicinity of urban areas and easy affordability of the urban class could account for the statistically significant difference between the two classes. Parent's reaction to their child's demand for a specific product revealed a statistically significant difference between urban and rural parents. Urban parents were more flexible than rural parents in fulfilling their children's demand. Cultural factors could be responsible for this, as in urban areas, mostly both parents are working to meet family's needs, whereas in rural areas, mostly single-income families exist, with the father being the main breadwinner.

Likewise, oral care advertisements were emphasized more by urban than the rural class, with a significant difference between the two categories. Urban parents were more aware of the importance of regular oral care. However, they showed poor attitude or indifference as most urban parents were not reminded of their dental needs by the appearance of a dentist on television. Urban parents were aware about sugar being the causative agent of dental caries and relied more on themselves for selection of toothpaste. According to both urban and rural parents, the same preventive measures in dental care could be followed by themselves and their kids, though the study showed a statistically significant difference between the two classes. Given the parallel views of both the classes on oral preventive measures, ignorance of different measures to be followed for adults and kids was reflected.

Although the urban class continued to dominate in the positive aspects of viewing habits, such as good knowledge of oral health and understanding the importance of oral care adverts, the negative aspects, such as poor attitude toward oral health despite good knowledge, more demanding children, parents fulfilling demands to a greater extent, etc., were far more in comparison and, thus, overshadowed the positive ones. There is an urgent need to address the damages inflicted on child population through advertisements directly or indirectly. Estimates show that imposing restrictions on advertising can significantly reduce obesity. ${ }^{21}$ Certain steps could be initiated within the framework proposed by the "Sydney Principles" (2006-2007), which could serve as a benchmark for considering regulation against child-oriented marketing practices.

Low-income countries suffer from fragmented regulation. ${ }^{22,23}$ Enforcing restrictions on advertising energy-dense, low-nutrient food and beverages on television could be initiated as a first step. Gradually, the scope could be enlarged to include all media sources. Simultaneously, parents, corporate sectors, government, and society should come together to support and implement complete prohibition of all forms of child-oriented advertising. Family environment also plays a positive role. An environment i.e., helpful and conducive to formation of good quality relationships among family members could influence the manner in which parents impose discipline on children, such as whether they are indulgent or strict and give in to demands. ${ }^{24,25}$ Lastly, teaching and educating youngsters not to be carried away by a colorful advert regarding a product, but critically view them is important.

As in a questionnaire study, this study has certain drawbacks. The validity and reliability are rather limited in scope. Its advantage is that change can be measured. However, bias can be incorporated as there is a level of subjectivity in such studies. There is also a tendency to give socially desirable answers. In addition, in a crosssectional study, such as the present, a causal link cannot be established. It is obvious that child-oriented marketing through television is influencing behavior of children in a negative manner. Improper food behavior is leading to obesity the world over. Surveys with a larger sample size are needed to assess the true magnitude of impact of television-mediated marketing on children and, gradually, put a complete stop on all forms of child-oriented marketing.

\section{CONCLUSION}

Television exerts a positive as well as negative influence on children's behavior among urban and rural communities, with the influence being more obvious in the urban class. Television as a medium should restrain adverts promoting high-calorie, sugar-rich snacks, which would result in improved oral and general health of children. The ultimate goal should be to enforce a complete ban on all forms of child-oriented marketing. This challenge can be met with the combined efforts of parents, the government, and society. 


\section{CLINICAL SIGNIFICANCE}

The results of this study can be utilized in bringing about better and effective advertising oriented toward attaining optimum oral health of children; promoting overall general health through adverts that discourage obesogenic diets and promote a diet rich in protein and fiber can also be focused on. The study also throws some light on the benefits of maintaining good family discipline and a positive dental attitude.

\section{REFERENCES}

1. Saxena, R. Marketing management. New Delhi: Tata McGraw; 2005.

2. Ramaswami, V.S.; Namakumari, S. Marketing management. 3rd ed. Macmillan; 2004.

3. Kavitha G. A study on the effectiveness of the advertising techniques used in the personal care segment of women consumers. Indian J Marketing 2006 Aug;36(8):12-16.

4. Datta S. Advertisements do they match consumer preferences? Marketing Mastermind 2008 Apr;4:59-62.

5. Gulla A, Purohit H. Children's attitude towards television advertisements and influence on the buying behaviour of parents. IJMFSMR 2013 Jun;2(6).

6. Dewan N, Thomson ML. When you buy, the kids decide. Economic Times 2010:5.

7. Goldberg M, Gorn G. Some unintended consequences of television advertising to children. J Consum Res 1978;5(1): 22-29.

8. McNeal. The kids market: myths and realities. 1st ed. Ithaca, NY: Paramount Market Publishing; 1999. J Consum Mark 2000;17(7):627-637.

9. Rossiter J. Reliability of a short test measuring children's attitudes towards TV commercials. J Consum Res 1977 Mar;3(4):179-184.

10. Oates C, Blades M, Gunter B. Children and television advertising: when do they understand persuasive intent? J Consum Behav 2002 Feb;1(3):238-245.

11. Bernard L, Lavelle C, Gray-Donald K, Deisle H. Overweight in CREE schoolchildren and adolescents associated with diet, low physical activity, and high television viewing. J Am Diet Assoc 1995 Jul;95(7):800-802.

12. Halford J, Boyland E, Hughes G, Stacey L, McKean S, Dovey T. Beyond-brand effect of television food advertisements on food choice in children: the effects of weight status. Public Health Nutr 2008 Sep;11(9):897-904.

13. American Psychological Association. Television advertising leads to unhealthy habits in children; says APA task force [press release]. Washington, DC: American Psychological Association; February 23, 2004. Available at: www.apa.org/ releases/childrenads.html.

14. Ward, S.; Wackman, D.B.; Wartella, E. How children learn to buy: the development of consumer information-processing skills. Beverly Hills, CA: Sage; 1977.

15. Escalante de Cruz, A. The junk food generation: a multicountry survey of the influence of television advertisements on children. Kuala Lumpur: Consumers International Asia Pacific Office; 2004.

16. Institute of Medicine. Food marketing to children and youth. Threat or opportunity? Washington, DC: National Academy of Sciences; 2006.

17. Dalmeny K. Food marketing: the role of advertising in child health. Consumer Policy Rev 2003 Jan;13(1):2-7.

18. Buijzen M, Valkenburg PM. The impact of television advertising on children's Christmas wishes. J Broadcast Electron Media 2000;44(3):456-470.

19. Pine KJ, Nash A. Dear Santa: the effects of television advertising on young children. Int J Behav Dev 2002 Nov;26(6):529-539.

20. Lobstein T, Dibb S. Evidence of a possible link between obesogenic food advertising and child overweight. Obes Rev 2005 Aug;6(3):203-208.

21. Haby MM, Vos T, Carter R, Moodie M, Markwick A, Magnus A, Tay-Teo KS, Swinburn B. A new approach to assessing the health benefit from obesity interventions in children and adolescents: the assessing cost-effectiveness in obesity project. Int J Obes 2006;30:1463-1475.

22. Unilever. Unilever strengthens its global commitment to responsible marketing. 2007. Available from: http:/ / www.unilever. com/ourcompany/newsandmedia/pressreleases/2007/ unileverresponsiblemarketing.asp.

23. Cadbury Schweppes. Corporate and Social Responsibility Report 2006, MarketingCode. 2007. Available from: http:/ / www.cadburyschweppes.com/EN/EnvironmentSociety/ Consumer/marketing_code.htm.

24. Duijster D, O'Malley L, Elison S, van Loveren C, Marcenes W, Adair PM, Pine CM. Family relationships as an explanatory variable in childhood dental caries: a systematic review of measures. Caries Res 2013;47(1):22-39.

25. Upadhayay A. The effect of advertising on children and adolescents - a critical appraisal. Int J Recent Res Rev 2012 Jun;2:48-52. 